\title{
STUDI KASUS ANALISIS PENDAPATAN USAHA KERIPIK KALAKAI IMUR DI KOTA PALANGKA RAYA
}

\author{
(Case Study Analysis of Operating Revenues Kelakai Chip in the City of Palangka Raya) \\ Asro Laelani Indrayanti ${ }^{1)}$, Nurul Hidayati ${ }^{2)}$ dan Nanang Hanafi ${ }^{3)}$ \\ ${ }^{3)}$ Dosen Fakultas Pertanian Universitas PGRI Palangka Raya \\ ${ }^{2)}$ Dosen Program Studi Agroteknologi Fakultas Pertanian dan Kehutanan \\ Universitas Muhammadiyah Palangkaraya \\ ${ }^{3)}$ Dosen Program Studi Kehutanan Fakultas Pertanian dan Kehutanan \\ Universitas Muhammadiyah Palangkaraya \\ e-mail : asroiin@yahoo.com
}

\begin{abstract}
Kalakai containing compounds or substances that included a functional food. One way is the use of plants kalakai processing into chips kalakai. Processed chips kalakai located in the city of Palangka Raya one of which is Imur.

The purpose of this study was to determine the production cost of chips kalakai imur, knowing revenue kalakai imur chips and determine the efficiency of the chips kalakai imur. This research was conducted in Jl. Manjuhan city of Palangka Raya. When the study will take place over four (4) months.

From the results of analysis show that (1) the cost of production of chips kalakai imur Rp. 10,141,200.00 during the period (per month), (2) income kalakai imur chips during the period (per month) Rp. 14.400.000,00, (3) Income/profit business kalakai imur chips during the period (per month) Rp. 4.258.800,00 (4) Efficiency of 1.4 imur kalakai chips.
\end{abstract}

Keywords: chips kalakai, cost, revenue, efficiency

\begin{abstract}
Abstrak
Kalakai mengandung senyawa atau zat yang termasuk pangan fungsional. Salah satu cara pemanfaatan tumbuhan kalakai adalah mengolah kalakai menjadi keripik kalakai. Olahan kripik kalakai yang terdapat di Kota Palangka Raya salah satunya adalah Imur.

Tujuan penelitian ini adalah untuk mengetahui biaya produksi keripik kalakai imur, mengetahui pendapatan keripik kalakai imur dan mengetahui efisiensi keripik kalakai imur. Penelitian ini dilakukan di Jl. Manjuhan Kota Palangka Raya. Waktu penelitian ini akan berlangsung selama 4 (empat) bulan.

Dari hasil analisis diketahui bahwa (1) biaya produksi keripik kalakai imur sebesar Rp. 10.141.200,00 selama satu periode (per bulan), (2) pendapatan keripik kalakai imur selama satu periode (per bulan) sebesar Rp. 14.400.000,00, (3) Pendapatan/keuntungan usaha keripik kalakai imur selama satu periode (per bulan) sebesar Rp. 4.258.800,00 (4) Efisiensi keripik kalakai imur sebesar 1.4. Hal ini menunjukkan bahwa usaha keripik kalakai imur layak diusahakan.
\end{abstract}

Kata kunci : keripik kalakai, biaya, pendapatan, efisiensi

\section{PENDAHULUAN}

Tanaman Kalakai merupakan salah satu jenis tumbuhan yang termasuk plasma nuftah di Kalimantan Tengah (BPTP, Kalimantan Tengah, 2008). Tanaman Kalakai (Stenochlaena palustris (Burm F)Bedd) adalah tanaman paku-pakuan yang tumbuh di daerah rawa gambut yang secara umum disebut lahan basah (MacKinnon et al. dalam Maharani et al., 2000). Botani kalakai termasuk dalam Kingdom Plantea, Sub Kingdom Viridaeplantae, Divisio Pteridophyta, Phylum Tracheophyta, Sub phylum Euphyllophytina, Ordo Filicales, Famili Blenchnaceae, Genus Stenochlaena, 
Spesies Stenochlaena palustris (Burm F)Bedd.

Kalakai dimanfaatkan untuk sayuran, mengobati penyakit kulit ringan, menurunkan demam dari dalam dan membersihkan darah, serta baik untuk menambah darah. Menurut data TAD (1981) dalam MacKinnon (2000) kalakai adalah tumbuhan sebagai sumber sayuran alternatif khas suku Dayak Kenyah di Long S Barang (Apo Kayan) dan Long Segar (S. Telen) Kalimantan Timur, bagian yang diambil batang dan daun. Secara spesifik, kalakai yang digunakan oleh suku dayak untuk mengobati anemia belum pernah diteliti, tetapi memberikan bukti yang nyata secara empiris (etnobotani). Kelakai berkhasiat mencukupi $\mathrm{Fe}$ pada ibu menyusui dan balita, pereda demam, mengobati sakit kulit, dan juga sebagai pencuci perut. Menurut Anonim (2008) kandungan gizi kalakai merah protein $(2,36 \%)$, serat kasar $(4,44 \%)$, lemak $(0,11 \%)$, abu (1,19\%), air $(89,09 \%)$, vitamin, mineral serta fitokimia lainnya yang bermanfaat untuk kesehatan. Kalakai mengandung senyawa atau zat yang termasuk pangan fungsional.

Pemanfaatan daun kalakai hanya untuk sayuran saja (bening, tumis, dan sop). Diversifikasi pangan lokal untuk masyarakat perlu dilakukan untuk meningkatkan keanekaragaman konsumsi pangan lokal di masyarakat. Dengan memanfaatkan potensi yang ada di daerah khususnya kota Palangka Raya dimana tanaman kalakai tumbuh subur dan banyak bisa dijadikan salah satu alternatif untuk diversifikasi makanan. Salah satu diversifikasi makanan yang berbahan baku dari kalakai adalah keripik daun kalakai.

Keripik kalakai imur merupakan salah satu produk oleh-oleh khas Kota Palangka Raya yang banyak digemari dan dicari oleh wisatawan baik lokal maupun luar. Produk keripik kalakai imur tersebar di beberapa pusat oleh-oleh Kota Palangka Raya, bandara, dan supermarket. Usaha pembuatan keripik kalakai imur merupakan usaha skala kecil yang berlokasi di Jalan Majapahit Kota Palangka Raya dan belum mempunyai analisis pendapatan yang dapat menjelaskan dan menginformasikan keadaan usaha ini. Untuk itu perlu dilakukan analisis pendapatan usaha keripik kalakai imur untuk memperoleh informasi-informasi dalam pengembanagan usahanya.

Tujuan penelitian ini adalah : a) mengetahui komponen biaya produksi keripik kalakai imur, b) mengetahui pendapatan keripik kalakai imur, dan c) mengetahui efisiesi usaha keripik kalakai imur.

\section{METODOLOGI}

\section{Tempat dan Waktu Penelitian}

Lokasi penelitian di Keripik Kalakai Imur, Kecamatan Pahandut Kota Palangka Raya. Pemilihan lokasi berdasarkan pertimbangan usaha ini dilakukan secara rutin, memiliki surat izin usaha seperti No PIRT dan Halal. Waktu penelitian dilaksanakan bulan September sampai November 2015. 


\section{Metode Pengambilan Data}

Penelitian ini menggunakan metode studi kasus. Data yang digunkaan adalah data primer (pengamatan, pencatatan dan wawancara langsung) dan data sekunder (studi pustaka).

\section{Analisis Data}

Analisis data yang dilakukan terhadap aspek pendapatan dengan menggunakan analisis kriteria sebagai berikut :

a. Menganalisis besarnya biaya pada usaha keripik kalakai imur. Biaya merupakan faktor yang sangat penting karena setiap rupiah biaya yang dikeluarkan akan mengurangi keuntungan usaha. Rumus yang digunakan dalam penyelenggaraan usaha ini adalah sebagai berikut :

$$
\mathrm{TC}=\sum_{\mathrm{i}=1}^{\mathrm{n}} \mathrm{Xi} . \text { Pxi }
$$

dimana :

$$
\begin{aligned}
& \mathrm{TC}=\text { Biaya Total } \\
& \mathrm{X}_{\mathrm{i}}=\text { Jumlah input yang digunakan } \\
& \mathrm{Pxi}=\text { Harga input } \\
& \mathrm{i} \quad=1,2,3, \ldots . . \mathrm{n}
\end{aligned}
$$

b. Sedangkan untuk menganalisis penerimaan dapat dihitung dari persamaan (Kasim, 2004) sebagai berikut :

$$
\mathrm{TR}=\sum_{\mathrm{i}=1}^{\mathrm{n}} \mathrm{Yi} \text {. Pyi }
$$

dimana :

$$
\begin{aligned}
\mathrm{TR} & =\text { Penerimaan Total }(\mathrm{Rp}) \\
\mathrm{Yi} & =\text { Jumlah output } \\
\mathrm{Pyi} & =\operatorname{Harga} \text { output }(\mathrm{Rp}) \\
\mathrm{i} \quad & 1,2,3, \ldots \ldots \ldots . . \mathrm{n}
\end{aligned}
$$

Untuk mengetahui besarnya keuntungan digunakan analisis pendapatan. Menurut Lipsey dan Richard (1995), rumus yang digunakan sebagai berikut :

Keuntungan $=$ Total Penerimaan - Total Biaya

Kriteria :

- Jika total penerimaan > total biaya, usaha untung

- Jika total penerimaan = total biaya, usaha tidak untung dan tidak rugi (impas)

- Jika total penerimaan < total biaya, usaha tersebut rugi

Pendapatan yang besar tidak selalu menunjukkan efisisensi tinggi karena ada kemungkinan pendapatan yang besar diperoleh dari investasi yang berlebihan, oleh karena itu analisis pendapatan selalu disertai dengan pengukuran efisiensi. Efisiesi suatu usaha atau kegiatan produksi terhadap pengguaan satu unit input digambarkan oleh nilai rasio penerimaan dan biaya yang merupakan perbandingan antara penerimaan kotor yang diterima dari setiap rupiah yang dikeluarkan dalam proses produksi. Analisis imbangan antara jumlah penerimaan dengan jumlah biaya merupakan suatu pengujian keuntungan suatu jenis usaha. Analisis imbangan penerimaan dan biaya (R/C ratio) didapat berdasarkan pembagian antara total penerimaan dengan total biaya. Rumus yang digunakan dalam análisis ini adalah :

$$
\mathrm{RCR}=\mathrm{TR} / \mathrm{TC}
$$

dimana:

$$
\begin{aligned}
\mathrm{RCR}= & \text { Revenue Cost Rasio } \\
\mathrm{TR}= & \text { Penerimaan total usaha keripik } \\
& \text { kalakai }
\end{aligned}
$$



$\mathrm{TC}=$ Total Cost/Biaya total usaha keripik kalakai

Suatu usaha ditanyakan efisien atau tidak efisien dengan kriteria sebagai berikut :

- $\mathrm{RCR}<1$, maka usaha keripik kalakai tidak efisien diusahakan.

- $\quad \mathrm{RCR}=1$, maka usaha keripik kalalai tidak untung dan tidak rugi.

- $\mathrm{RCR}>1$, maka usaha keripik kalalai efisien untuk diteruskan.

Digunakannya metode RCR sebagai alat analisa untuk mengetahui kelayakan, karena cara ini lebih mudah dalam menganalisa.

\section{HASIL DAN PEMBAHASAN}

Analisis pendapatan bertujuan untuk melihat usaha keripik kelalai imur yang sedang berjalan, dalam hal ini analisis pendapatan usaha keripik kelalai imur menunjukkan struktur biaya yang dikeluarkan dan penerimaan yang diperoleh dari usaha keripik kelalai imur. Perhitungan analisis pendapatan dilakukan selama satu periode usaha per bulan. Hasil analisis biaya dan pendapatan usaha keripik kelalai dapat dilihat pada Tabel 1.

Dalam usaha keripik kalakai imur biayabiaya yang dikeluarkan selama satu periode meliputi biaya pembelian bahan baku, pembayaran listrik, pembelian bensin, biaya penyusutan dan biaya tenaga kerja. Jumlah biaya yang dikeluarkan selama satu periode produksi keripik kalakai imur sebesar Rp. 10.141.200,00.
Penerimaan merupakan hasil perkalian antara total produksi denga harga jual. Dalam satu periode produksi keripik kalakai per bulan dihasilkan keripik kalakai sebanyak 1.440 bungkus. Harga jual per bungkus Rp. 10.000,00. Jumlah penerimaan selama satu periode sebesar Rp. 14.400.000,00.

Pendapatan usaha keripik kalakai imur merupakan selisih antara penerimaan dan semua biaya. Nilai pendapatan keripik kalakai imur selama satu periode sebesar Rp. 4.768.800,00.

Nilai pendapatan menunjukkan bahwa usaha keripik kalakai imur ini menguntungkan untuk dilakukan. Selain dilihat dari segi pendapatannya dapat juga dilihat dari efisiensinya dengan membandingkan nilai penerimaan dengan biaya yang dikeluarkan selama satu periode (per bulan) yaitu nilai $\mathrm{R} / \mathrm{C}$ ratio. Nilai $\mathrm{R} / \mathrm{C}$ ratio selama satu periode (per bulan) usaha keripik kelalai imur sebesar 1.4. Hasil ini menunjukkan bahwa analisis ekonomi $\mathrm{R} / \mathrm{C}$ ratio usaha keripik kalakai berada di atas angka 1, sehingga dalam hal ini dapat disimpulkan bahwa usaha keripik kalakai imur efisien untuk diusahakan atau layak untuk diusahakan. Dari hasil nilai R/C sebesar 1.4 berarti setiap Rp. 1,- biaya yang dikeluarkan usaha ini akan menghasilkan penerimaan sebesar Rp. 1.4,- 
Tabel 1. Analisis biaya dan pendapatan usaha keripik kelakai selama satu periode (Rp/bulan)

\begin{tabular}{|c|c|c|c|c|c|}
\hline No. & Uraian & Volume & Satuan & Harga Satuan & Jumlah \\
\hline 1. & Penerimaan & 1,440 & bungkus & 10,000 & $14,400,000$ \\
\hline \multirow[t]{17}{*}{2.} & Biaya & & & & \\
\hline & * Daun Kelalai & 360 & ikat & 1,800 & 648,000 \\
\hline & * Tepung Beras & 72 & $\mathrm{~kg}$ & 10,000 & 720,000 \\
\hline & * Tepung Tapioka & 6 & $\mathrm{~kg}$ & 5,000 & 30,000 \\
\hline & * Bawang Putih & 4.8 & $\mathrm{~kg}$ & 34,000 & 163,200 \\
\hline & * Ketumbar & 0.6 & $\mathrm{~kg}$ & 25,000 & 15,000 \\
\hline & * Minyak Goreng & 96 & liter & 15,000 & $1,440,000$ \\
\hline & * Keminting & 12 & $\mathrm{~kg}$ & 28,000 & 336,000 \\
\hline & * Telur & 180 & butir & 1,500 & 270,000 \\
\hline & * Garam & 3 & bungkus & 1,000 & 3,000 \\
\hline & * Standing Pouch + Stiker & 1,440 & bungkus & 1,350 & $1,944,000$ \\
\hline & * Tenaga Kerja & 2 & orang & $2,000,000$ & $4,000,000$ \\
\hline & * Gas & 12 & Tabung & 21,000 & 252,000 \\
\hline & * Listrik & 1 & bulan & 120,000 & 120,000 \\
\hline & * Bensin & 20 & liter & 7,500 & 150,000 \\
\hline & * Penyusutan & 1 & bulan & 50,000 & 50,000 \\
\hline & Total Biaya & & & & $10,141,200$ \\
\hline 3. & Keuntungan & & & & $4,258,800$ \\
\hline 4. & $\mathrm{R} / \mathrm{C}$ & & & & 1.4 \\
\hline
\end{tabular}

\section{SIMPULAN}

1. Biaya yang dikeluarkan dari usaha keripik kalakai imur selama satu periode (per bulan) sebesar Rp. 10.141.200,00.

2. Penerimaan hasil dari penjualan keripik kalakai imur selama satu periode (per bulan) sebesar Rp. 14.400.000,00.

3. Pendapatan atau keuntungan selama satu periode (per bulan) usaha keripik kalakai imur sebesar Rp. 4.258.800,00.

4. Efisiensi keripik kalakai imur selama satu periode (per bulan) sebesar 1.4. Artinya usaha keripik kalakai imur layak untuk dijalankan (menguntungkan).

\section{DAFTAR PUSTAKA}

Anonim. 2008. Kalakai Sayuran Exotik Kalimantan Tengah. Sinar Tani On Line.

Balai Penelitian Tanaman Pangan Kalimantan Tengah. 2008. Mengenal Sayuran Kalakai. BPTP Kalimantan Tengah. Palangka Raya.

Kasim S. 2004. Petunjuk Menghitung Keuntungan dan Pendapatan Usahatani. Universitas Lambung Mangkurat. Banjarbaru.

Lipsey dan Richard G. 1995. Pengantar Mikroekonomi Intermediate. Edisi 3. Rajawali Press. Jakarta.

MacKinnon., dkk. 2000. Ekologi Kalimantan Edisi III. Jakarta. 
Maharani, Haidah, and Hainiyah. 2006. Studi Potensi Kalakai Sebagai Pangan Fungsional. Kumpulan Makalah PIMNAS XIX, 26-29 Juli di Universitas Muhamadiyah Malang. 